\title{
Digital cultural heritage and rural landscapes: preserving the histories of landscape conservation in the United States
}

\author{
Sarah Karle ${ }^{1 *}$ and Richard Carman ${ }^{2}$
}

\begin{abstract}
This paper addresses how a digital heritage project can impact the research and interpretation of a large-scale rural cultural landscape in the United States. Due to the size and scope of rural landscapes, large-scale documentation methods are critical to advancing landscape conservation and preservation initiatives. Using an in-progress online project to document a 1935 US federally sponsored program, the Prairie States Forestry Project (PSFP), the authors show how diverse visual and textual data can be spatialised to construct a map reading of landscape change over time. To date, the PSFP is one of the largest afforestation projects in the history of the United States; the United States Forest Service and thousands of landowners undertook a series of cooperative planting agreements to plant over 200 million trees over seven years in approximately 33,000 shelterbelts from the panhandle of Texas to the North Dakota border. Due to a lack of coordinated monitoring, shelterbelt location and status was unknown, and the original archival material remained unpreserved. In the case of the Prairie States Forestry Project, the process for digitising and disseminating previously inaccessible primary source documents is an act of preservation that creates opportunities for future large-scale landscape conservation projects. The application of the archival mapping method and resulting PSFP datasets can be incorporated by individuals working on heritage documentation such as Historic American Landscapes Survey (HALS) reports, National Register nominations, or Cultural Landscape Reports for the National Parks Service. The dataset could also be used by private groups such as cooperative conservation land managers.
\end{abstract}

Keywords: Historical GIS, Cultural landscape documentation, Large-scale landscape preservation and conservation

\section{Introduction}

The adoption of agroforestry practices in Nebraska can be traced to the Prairie States Forestry Project (PSFP) of the US Forest Service (1935-1942).
Through the PSFP, thousands of shelterbelts ${ }^{1}$ and riparian buffers were planted to slow wind and protect the soil during the Dust Bowl (1935-1942), and the project represents a significant moment in the history of ecological engagement in the Great Plains.

\footnotetext{
* Correspondence: Skarle@unl.edu

'University of Nebraska-Lincoln, Lincoln, Nebraska, USA

Full list of author information is available at the end of the article
}

\footnotetext{
${ }^{1}$ Shelterbelts, also called windbreaks, are rows of trees typically planted adjacent to agricultural fields to protect crops and conserve soil against strong winds.
}

\section{Springer Open}

( ) The Author(s). 2020 Open Access This article is licensed under a Creative Commons Attribution 4.0 International License, which permits use, sharing, adaptation, distribution and reproduction in any medium or format, as long as you give appropriate credit to the original author(s) and the source, provide a link to the Creative Commons licence, and indicate if changes were made. The images or other third party material in this article are included in the article's Creative Commons licence, unless indicated otherwise in a credit line to the material. If material is not included in the article's Creative Commons licence and your intended use is not permitted by statutory regulation or exceeds the permitted use, you will need to obtain permission directly from the copyright holder. To view a copy of this licence, visit http://creativecommons.org/licenses/by/4.0/. 
This heritage, however, is at risk due to a lack of coordinated monitoring efforts; the current status of existing PSFP shelterbelts remains unknown, making it difficult to identify and analyse the evolution of this large-scale cultural landscape.

As a part of American agricultural heritage, PSFP shelterbelts may be listed on the National Registry of Historic Places, provided proper documentation is submitted. In the National Register Bulletin Guidelines for Evaluating and Documenting Rural Historic Landscapes, McClelland et al. $(1999,9)$ identified New Deal soil conservation projects like the PSFP as historically significant:

Beginning in the 1930s, the U.S. Soil Conservation Service assumed an active role in shaping American farms by recommending the planting of wind breaks [shelterbelts], revitalisation of soils, contour plowing, and other techniques.

The application of an archival mapping method and resulting PSFP datasets can be incorporated by individuals working on heritage projects such as Historic American Landscapes Survey (HALS) reports, National Register nominations, cultural landscape reports, historical landscape studies related to Section 106 and 110 review, and preliminary archaeological surveys (Sabol et al. 2018, 2).

Additionally, cultural resource professionals working with a heritage landscape such as the PSFP have challenges identifying and evaluating large-scale landscapes with 'dynamic plant material' and 'easily modified spatial conditions' (Sabol et al. 2018, 1). Mapping methods are needed to reduce the amount of fieldwork necessary for spatial analysis on such a massive scale. Cultural resource managers can look to the disciplines of archaeology, landscape ecology, and history to identify several novel approaches to documenting landscape change over time using Geographic Information Systems (GIS) that can be applied to preservation and conservation efforts (Sabol et al. 2018, 4). Scholars working in the field of largescale landscape conservation for the National Park Service have also noted that 'what gets mapped gets saved' (Barrett 2018). In this context, historical GIS methods serve not only as a research tool but can also identify and evaluate opportunities for future preservation and stewardship of the PSFP shelterbelts.

This project discusses the application of a historical GIS archival mapping process, referred to as 'data capture', in the generation of a number of geospatial PSFP datasets for the state of Nebraska (Gregory $2003,103)$. The data capture method uses a combination of location, attribute data, and dates provided in archival sources to establish the foundation for new
GIS datasets documenting a large-scale cultural landscape. These datasets are critical to providing the necessary documentation for preservation and conservation research in three ways, serving as:

(a) a starting point for inventorying and evaluating the existing condition of the PSFP shelterbelts;

(b) a way to visualise how the shelterbelts changed over time;

(c) and as a way to connect historical research to conservation efforts, creating a powerful tool that links cultural and natural resources.

\section{American New Deal heritage preservation}

New Deal preservation and conservation initiatives for tangible heritage ${ }^{2}$ projects are underway across the United States. State Historic Preservation Offices (SHPO) submit project nominations to the United States National Park Service for consideration and placement on the National Register of Historic Places. Several states, including Nebraska, have developed a Multiple Property Documentation Form (MPDF) for listing a group of New Deal-related resources to the National Register of Historic Places. Nebraska's MPDF form identifies the Prairie States Forestry Project as a significant New Deal conservation effort that shaped the state's landscape heritage from 1935 to 1942 . The document identifies the project as 'nationally significant' due to its multi-state scale:

Resources spanning multiple counties or affecting multiple municipalities likely will be eligible [for nomination] on a statewide level....as such, few resources are expected to be nationally significant. Exceptions to this may be highly intact resources related to multi-state projects or exceptionally significant properties representing the best national example of a type. A potential example of a nationally significant resource would be a highly intact remnant of the Prairie States Forestry Project, which planted over 220 million trees in shelterbelts from North Dakota south to Texas; within this area, Nebraska planted more trees than any other state. (Loughlin and Rosin 2019, SF_2)

Despite the project's national significance, a critical nomination component includes physical documentation inventorying and evaluating existing historical landscape conditions. Due to the large size of the project, a

\footnotetext{
${ }^{2}$ The federal New Deal support created tangible (physical resources) and intangible results (salaries for jobs). The focus, however, of the Nebraska Statewide New Deal Era Resource of Nebraska MPDF (2019, F_1) is only on the physical resources produced as part of the New Deal and includes examples from fire stations to rural resettlement developments to shelterbelts across the state of Nebraska.
} 
comprehensive mapping method is needed to inventory and document the existing project's condition prior to establishing preservation or management plans. Although historical aerial photographs are publicly available and can document land use and land cover change, it would be challenging to identify whether a specific shelterbelt is part of the historically significant New Deal project from aerials alone. For the PSFP, primary source maps, reports, pamphlets, and bulletins created by the US Forest Service during the project's implementation are located in the USDA National Agroforestry Center (NAC) archives and are necessary for identifying and evaluating the current condition of the historic shelterbelts.

\section{Research methods Study area}

The original plantings of several Great Plains shelterbelts were part of the Prairie States Forestry Project (PSFP), one of the largest afforestation projects in US history. The federal project was part of the American New Deal, which began when Franklin D. Roosevelt (FDR) took office as president of the United States in 1933. As president, FDR established a series of experimental programs and projects to address unemployment issues faced by Americans during the Great Depression (1929-1939). During the Depression, Great Plains farmers were devastated by a combination of bank failure (resulting in loss of savings), extreme environmental drought, and suffocating dust storms, which rendered their land useless (McLeman et al. 2014, 418) (Fig. 1). This 'Dust Bowl' period impacted millions of acres of farmland, resulting in 'distress migration on scales not previously seen' (McLeman et al. 2014, 418).
In response to economic and environmental crises, FDR instituted a series of programs and projects aimed at addressing soil conservation and introducing new farming techniques across the region. During his first 100 days, FDR established the Civilian Conservation Corps (CCC) and the Soil Erosion Service, which later became the Soil Conservation Service, known today as the Natural Resource Conservation Service. Historian Woolner (2010) noted in his essay, 'FDR and the New Deal Response to an Environmental Catastrophe', that 'the establishment of the Soil Erosion Service marks the first major federal commitment to the preservation of natural resources in private hands'. As part of federal soil conservation efforts, the experimental PSFP shelterbelt planting program was implemented in 1935. The size and scope were ambitious, and the federal project was achieved through cooperative planting agreements between the United States Forest Service and private landowners: from 1935 to 1942, the PSFP planted over 200 million trees in approximately 33,000 shelterbelts on private land across 18,599 miles (Perry 1942, 1) (Figs. 2 and 3).

The PSFP was managed originally by the US Forest Service, but by 1938 the Secretary of Agriculture, Henry A. Wallace (1933-1940), began to phase out the Forest Service's involvement with the project and shifted responsibility for 'farm forestry function' into the conservation programs of the Soil Conservation Service (Droze 1977, 219). By 1942, one-fourth of the shelterbelt zone had been organised into soil conservation districts. As the United States entered World War II (1941-1945), a labour shortage and decreased financial support provided by the Soil Conservation Service resulted in a decline in shelterbelt planting as a conservation strategy across the Great Plains (Droze 1977, 227). A comprehensive and coordinated shelterbelt monitoring effort by the United States Soil

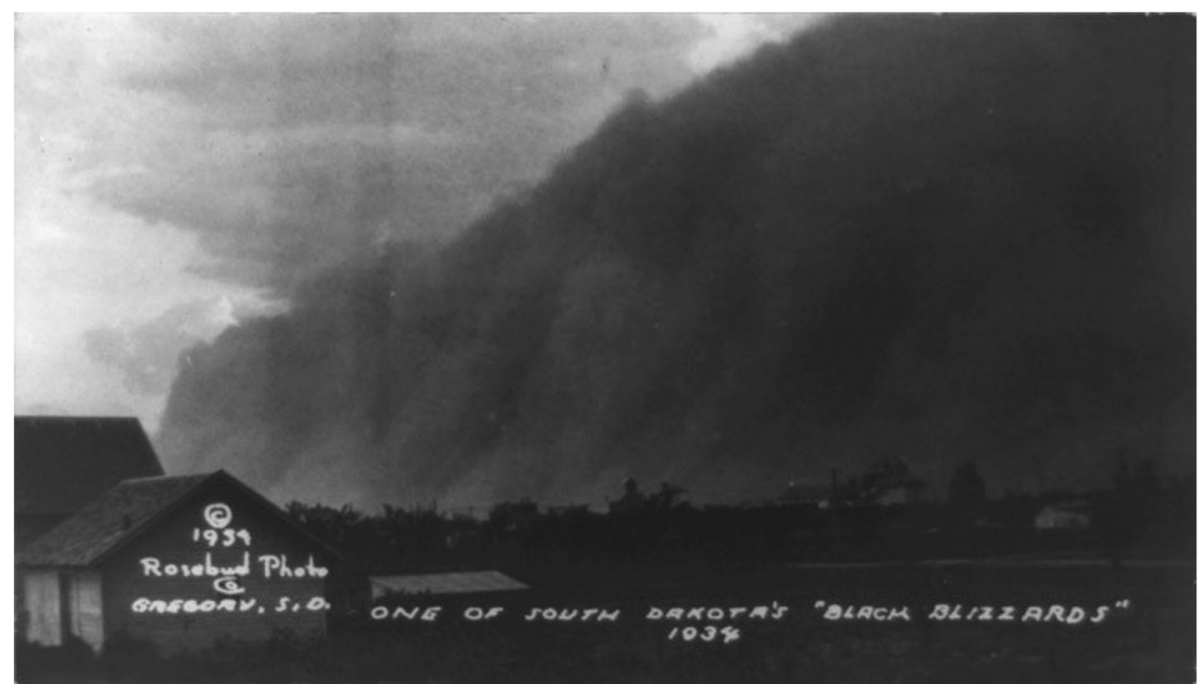

Fig. 1 A 'black blizzard' dust storm in South Dakota. May, 1934. (Source: the Library of Congress, Prints \& Photographs Division, FSA/OWI Collection, [LC-DIG-fsa-8b31259]) 


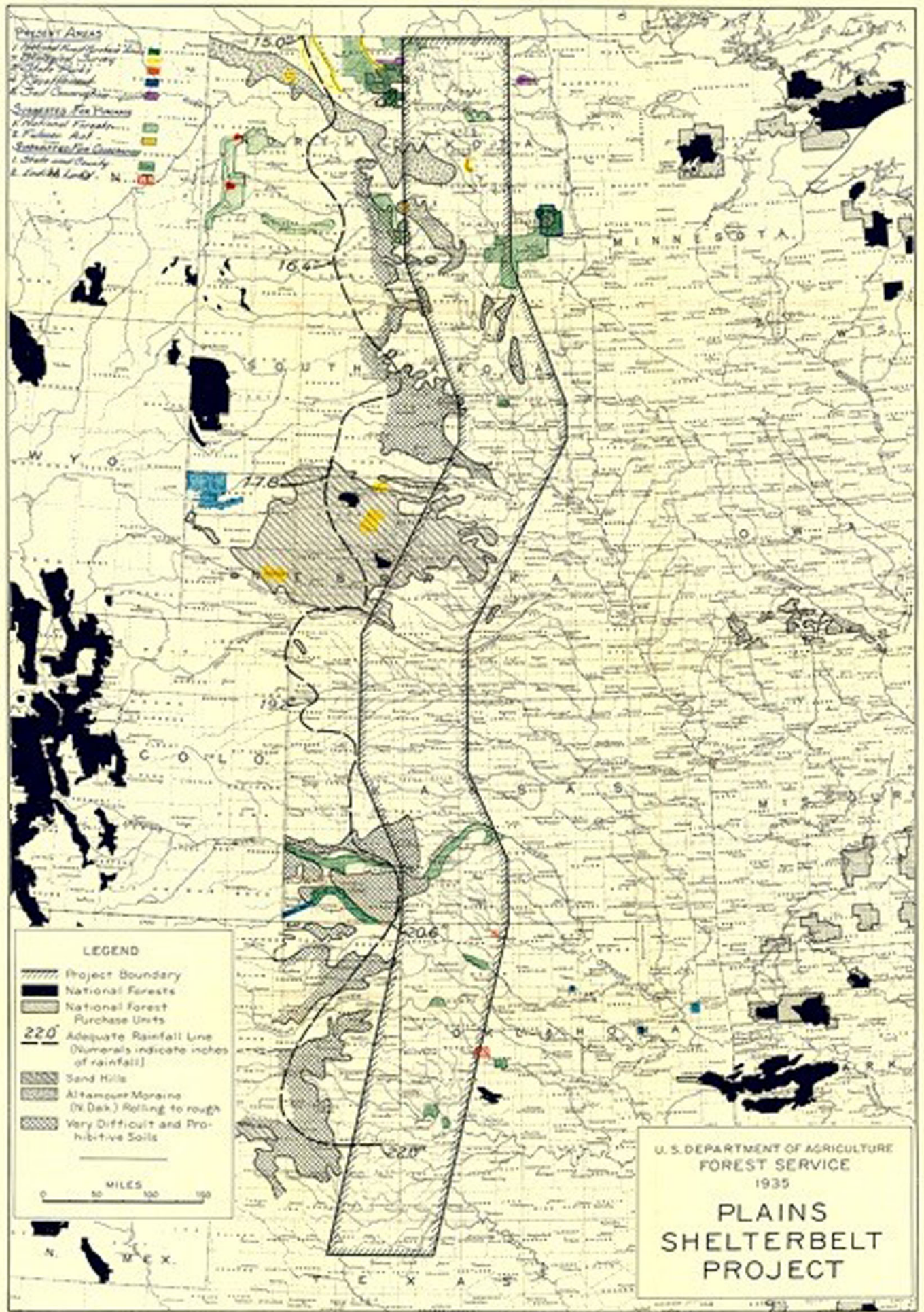

Fig. 2 Final published shelterbelt zone. February, 1935. Originally published in Possibilities of Shelterbelt Planting in the Plains Region. (Source: the Forest Service, U.S.D.A) 


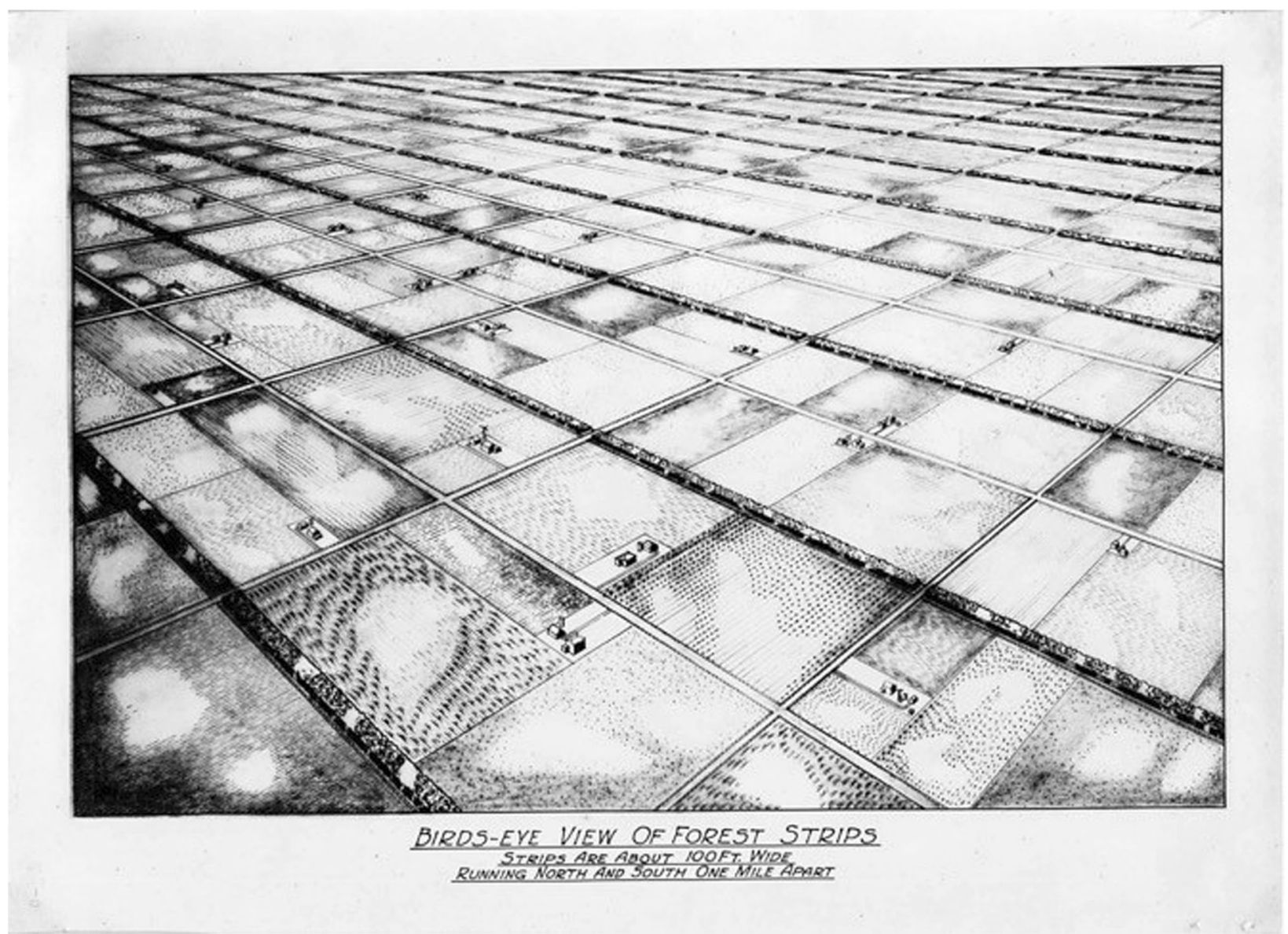

Fig. 3 Artistic representation of shelterbelt spacing. Strips are about $100 \mathrm{ft}$ wide, running north and south one mile apart. Lake States Forest Experiment Station. 1934. (Source: the Forest Service, U.S.D.A)

Conservation Service did not occur after the project's transfer from the United States Forest Service, making identifying the location of existing PSFP shelterbelts challenging for cultural and natural resource managers. Until recently, only anecdotal evidence existed indicating that many Great Plains shelterbelts, including those originally planted in the PSFP, have been removed from the landscape due to increased crop prices, new farming techniques, and age-related deterioration (Liknes et al. 2017, 167).

\section{Archival research}

The PSFP headquarters were located in Lincoln, Nebraska, and original archival materials remain unpreserved at the USDA National Agroforestry Center (NAC) on the University of Nebraska-Lincoln's (UNL) campus. In 1940, then project director Paul Roberts wrote a letter to all participating Forest Service state directors and division chiefs encouraging them to keep a permanent record of the project, saying, 'You may not attach much importance to some of them, but send them in any way, for out of all of this someday someone will write a saga of the Shelterbelt. (Roberts, 1940)' Robert's efforts resulted in the NAC collection retaining documents for the three participating northern states, Nebraska, South Dakota, and North Dakota, with limited documentation for the southern project states of Texas, Kansas, and Oklahoma. The archival collection covers 1935-1942 and includes primary source textual material, including correspondence and cooperative planting agreements between the Forest Service project administers and private landowners referred to as cooperators. The US Forest Service cartographically recorded the PSFP using public land survey maps, placing them in the NAC archive. Additionally, each cooperator's shelterbelt planting was supported by descriptive records, which included information on the quantity of species planted as well as the length and width of each shelterbelt. The documents are located in filing cabinets organised by participating states. Nebraska, for example, has 150 county maps, 1000 township maps, and over 6000 descriptive records.

Photography is also included in the collection, with over 6000 printed photographs taken by project administers and New Deal photographers hired to document the progress of the federally funded project (Fig. 4). Several duplicate photographs are stored in filing cabinets and 


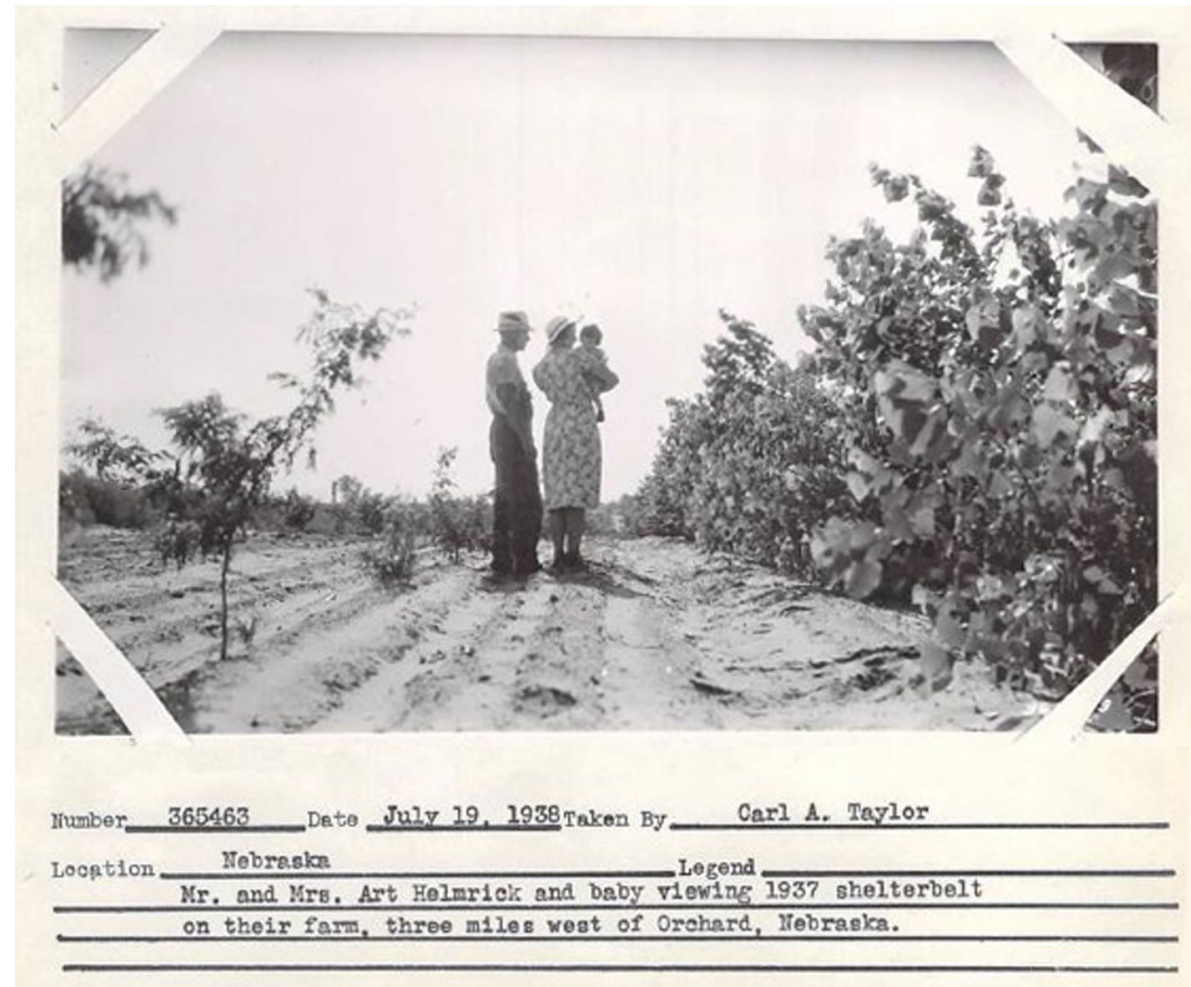

Fig. 4 Archival Source Photography. Mr. and Mrs. Art Helmrick and baby viewing a 1937 shelterbelt on their farm (photo taken in 1938). (Source: National Agroforestry Centre - Forest Service)

photo albums. Photographs are labeled with an archival number that can be traced to negatives stored in the $\mathrm{Na}$ tional Archives in Washington, DC, the date the photograph was taken, and the name of the photographer. The location is typically listed as a state or county with a supporting description of the planting site and the name of the cooperator if included in the picture. Additionally, photographs were not organised in the archive by location but by classification tags: shelterbelt, utilisation, damage, field windbreaks, crop protection, and human interest. The thematic archival photographic classification system makes identifying and spatially locating photographs challenging.

One important archival record that was identified for our cartographic purposes was the 'Township Maps' (Fig. 5). The archival township maps contained colourcoded plantings for all eight years of the project as well as the transcribed original landowner's name to farm number. These maps became the basis for generating spatial data. The combination of location, attribute data, and planting dates in the archival sources provided the foundation for a data capture process in GIS.

Through the historical reconstruction of the PSFP, it is possible to identify the current condition of today's remaining shelterbelts. For this research, historical sources (maps, records, and photographs) can reconstruct the history of this large-scale cultural landscape using GIS technology. The methodological goal is to apply what historian Anne Knowles calls a 'historical GIS' approach, combining archival research with modern GIS technology to document cultural landscape change (Knowles 2005, 7). Historical GIS combines methods from historical geography with spatial and digital history to address geographic questions associated with time and place (Knowles and Hillier 2008, 7). The majority of scholarship in this area presents historical evidence as a geographic argument in visual forms, such as thematic maps (Knowles and Hillier 2008, 7). In their book, Placing History: How Maps, Spatial Data, and GIS are Changing Historical Scholarship, Knowles and Hillier identify three areas of historical GIS scholarship:

One is empirical research on the history of land use and the development of spatial economies. The second is using GIS to visualise past landscapes and the changing morphology of the built environment over time. The third consists of infrastructure projects that aim to make historical source materials available to scholars and the general public for mapping and other kinds of analysis. (8) 
Tarm 97s.

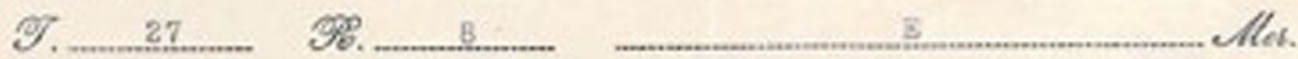

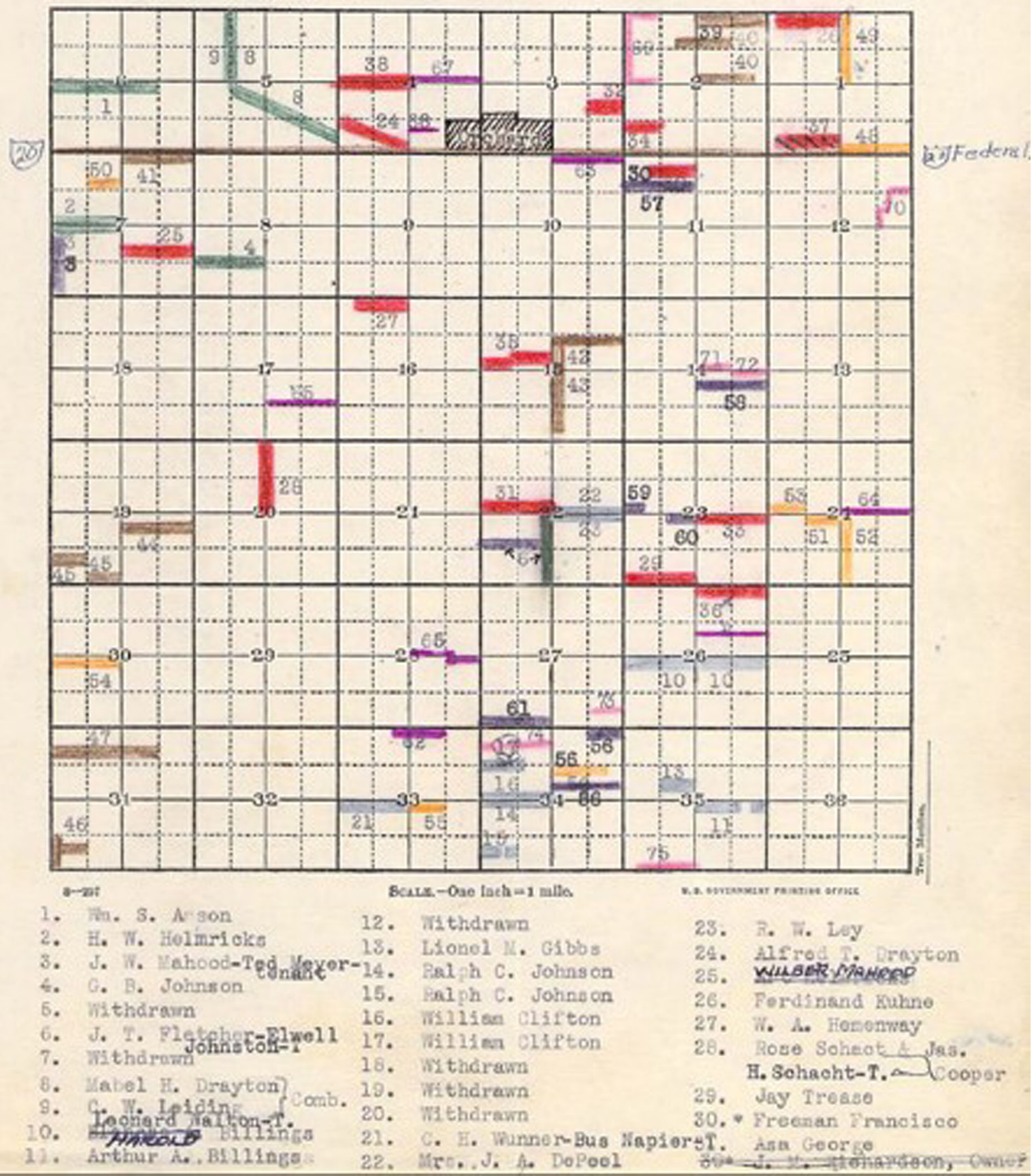

Fig. 5 Archival Source Township Map. Township map with cooperator's name and farm number (Farm \#25 changed ownership Art Helmrick Wilber MaHood). (Source: National Agroforestry Centre - Forest Service) 
Table 1 Data provider, source, and spatial layers used in the study area of Nebraska

\begin{tabular}{|c|c|c|}
\hline Data Provider & Source & Layers \\
\hline Township Maps & NAC Archive & Historic Shelterbelts planted from 1935 to 1942 \\
\hline $\begin{array}{l}\text { U.S. Department of Agriculture's } \\
\text { Natural Resource Conservation } \\
\text { Service (NRCS 2016) }\end{array}$ & https://datagateway.nrcs.usda.gov & $\begin{array}{l}\text { Background data for state and county boundaries, } \\
\text { Public Land Survey System (township and range) } \\
\text { boundaries, roads, and populated areas. }\end{array}$ \\
\hline $\begin{array}{l}\text { U.S. Department of Agriculture's } \\
\text { National Agriculture Imagery } \\
\text { Program (NAIP 2016) }\end{array}$ & $\begin{array}{l}\text { https://www.fsa.usda.gov/programs-and-services/aerial- } \\
\text { photography/imagery-programs/naip-imagery/ }\end{array}$ & 2016 Aerial Images for the State of Nebraska \\
\hline
\end{tabular}

This project contributes to Knowles and Hillier's second and third areas of scholarship, 'reconstructing past landscapes' and 'infrastructure projects' by applying a historical GIS method referred to by geographer Gregory $(2003,103)$ as 'data capture' in which data from archival maps are translated into a publicly accessible GIS dataset. In addition to scholarly research, a novel approach for historical GIS methods can be applied by individuals or agencies working to preserve and provide stewardship for cultural landscapes (Donahue 2008, 174). In the context of the PSFP, the historical GIS method serves not only as a research tool but can also identify and evaluate opportunities for future preservation and stewardship of the PSFP shelterbelts.

\section{GIS modeling}

\section{Data acquisition}

For this investigation, Nebraska was selected as the study area, and 1000 archival township maps that include over 10,000 planted shelterbelts were manually digitised. Geo-referenced vector data was downloaded from the Natural Resource Conservation Service (NRCS) and formatted in ArcGIS as additional layers for the mapping process. Raster data was included from the National Agricultural Image Program (NAIP), which acquires and disseminates aerial images during the agricultural growing season. Aerial photography is taken by NAIP (2016) on a three- to five-year cycle, and aerial GeoTIFF from 2016 were downloaded as digital ortho quarter quad tiles (DOQO) for this study (Table 1).

\section{Vector database with attribute data}

A vector database was created from the historical township map and entered manually as a line in ArcGIS. Because the archival township maps were drafted to scale and descriptive data for length was available for each shelterbelt planted, manual entry was possible. Shelterbelts are typically quantified by miles planted (length) and provided the rationale for recording the belts as lines instead of polygons representing the area. Once each shelterbelt feature was digitised as a line, appropriate attribute data was added from the descriptions on the township maps: cooperator's (landowner's) name, year of planting, and legal description of the location, including farm identification number (Table 2).

An alternative process, described by Rumsey and Williams $(2002,5)$ as 'rubber sheeting', allows one to overlay maps from different eras and adjust the transparency of the layers until the evidence of change in the maps is visible in GIS. The rubber sheeting process, however, would have required additional steps in the process, including the scanning of thousands of archival documents. Therefore, we decided to enter the length of each shelterbelt planted manually.

\section{Overlay analysis using raster data}

The historical shelterbelt vector layers were overlaid on current aerial geo-data, making it possible to analyse and visualise remaining shelterbelts in GIS (Fig. 6). Three categories were established to classify each shelterbelt's existing condition in 2016 (removed shelterbelts, partially intact shelterbelts, and fully intact shelterbelts). The condition of the shelterbelt was analysed based on visual evidence matching the archival documents of the remaining

Table 2 Fields in attribute table for each shelterbelt planting

\begin{tabular}{|c|c|c|c|c|c|c|c|c|}
\hline Id & Map ID & Name & Year Planted & $S$ & T_R & Farm ID & County & Stat_2016 \\
\hline 0 & $35-1$ & Johnston, CE \& James & 35 & 5 & $\mathrm{~T} 27 \mathrm{~N}-\mathrm{R} 7 \mathrm{~W}$ & 1 & Antelope & Partial \\
\hline 0 & $35-2$ & Johnston, CE \& James & 35 & 5 & T27N-R7W & 1 & Antelope & Partial \\
\hline 0 & $36-1$ & Smallwood, OM & 36 & 16 & $\mathrm{~T} 23 \mathrm{~N}-\mathrm{R} 8 \mathrm{~W}$ & 9 & Antelope & Partial \\
\hline 0 & $36-2$ & Johns, AE & 36 & 16 & $\mathrm{~T} 23 \mathrm{~N}-\mathrm{R} 8 \mathrm{~W}$ & 10 & Antelope & Removed \\
\hline 0 & $37-156$ & Frazier Bros. & 37 & 7 & T27N-R7W & 38 & Antelope & Intact \\
\hline 0 & $37-157$ & Pederson, Denker & 37 & 13 & T23N-R8W & 26 & Antelope & Intact \\
\hline
\end{tabular}


historical planting patterns (length and continuity of planting) resulting in continual land use (performance) as an agricultural conservation measure.

A fully intact shelterbelt retained over $75 \%$ of its original planting structure, as evident in the aerial photography, maintained original length and appropriate continuity, and continues to function as a wind buffer. Partially intact shelterbelts were belts that retained $6 \%$ to $74 \%$ of their original planting structure, with the goal of inventorying as many partially intact plantings as possible. A partially intact shelterbelt, for example, could have maintained several rows in width but had significant gaps in length that could compromise the original designed land use and performance. Additional research would be necessary to determine which partially intact shelterbelts continue to function as a conservation measure. If less than $5 \%$ of a shelterbelt's planting structure remained, the planting was classified as removed. Additional fields, including a GIS-designated reference number, were added to the attribute data, classifying each planting as fully intact, partially intact, or removed (Table 2).

\section{Analysis}

Cultural resource professionals working with heritage landscapes, such as the PSFP, experience challenges documenting historical conditions and evolution of large-scale landscapes. The conversion of archival data into GIS, which was completed using historical township maps overlaid on current aerial photography, enables a cultural resource manager to locate sites potentially eligible for the National Register across a vast landscape scale. Therefore, the reviewer has access to data needed to identify and evaluate the landscape's existing condition without extensive fieldwork.

Given the regional scale of the project (a zone of planting stretching across six states or 18,599 miles of shelterbelts), it is critical to organise documentation for a multitude of sites contained within one map. Our vector data located and spatialised a comprehensive reading of the project across a new, larger landscape-scale (state scale) previously not possible within the confines of printed maps. The attribute data in our GIS data set can be queried, allowing the dynamics of landscape change

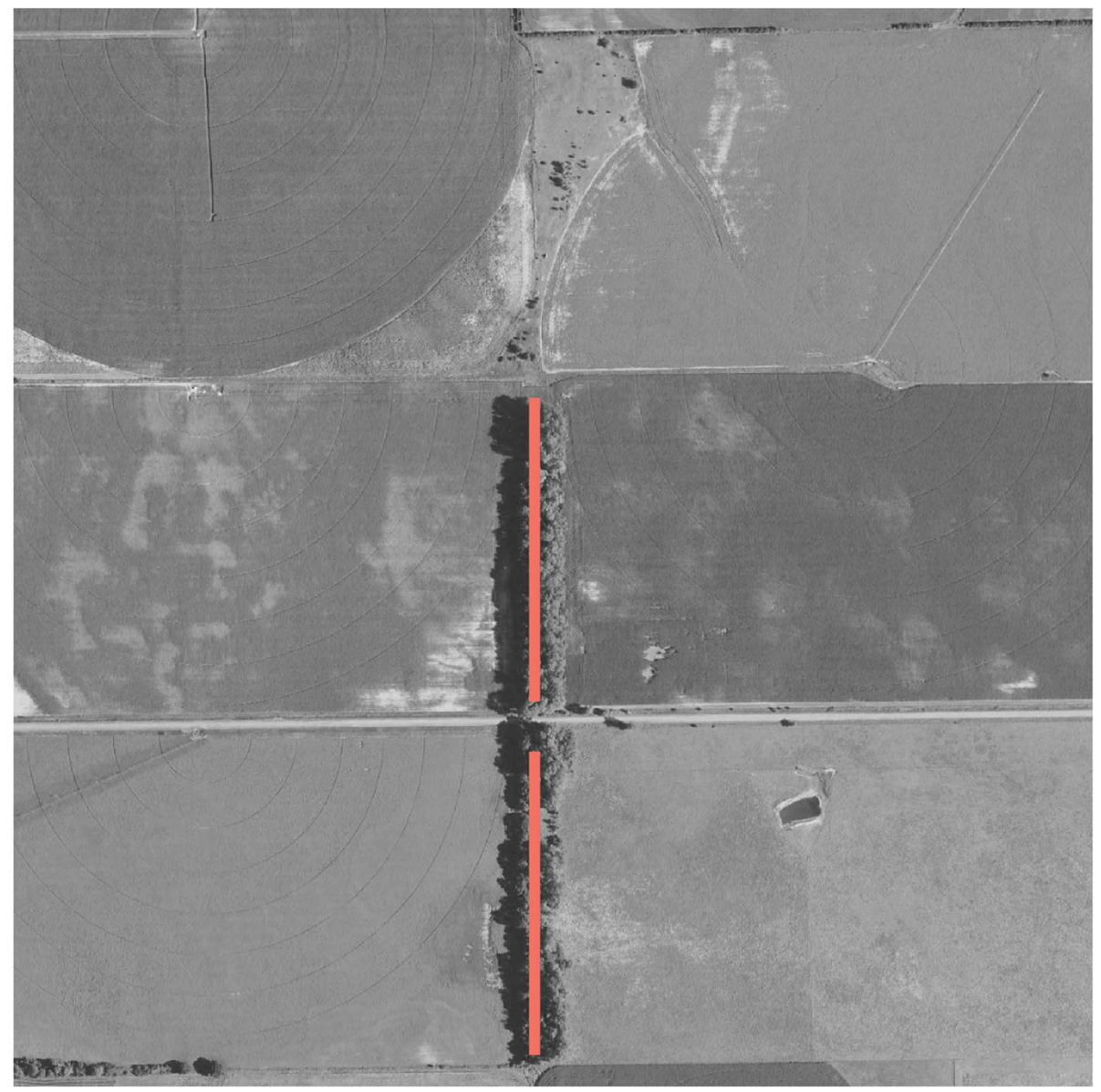

Fig. 6 Overlay Analysis identifying fully intact PSFP shelterbelt (Source: the authors) 
to be displayed and quantified through thematic cartographic maps and summary tables.

Determination of an intermediate scale for statistical analysis was critical in assembling data into GIS, allowing for analysis not only of individual sites but of the entire state. An important historical element of the PSFP is the large-scale design of the project, and therefore the aggregation of multiple shelterbelts in the landscape also contributes to the project's land use and conservation performance. As historian Cunfer $(2008,103)$ illustrates in his historical GIS project, Scaling the Dust Bowl, which investigates the relationship between agricultural methods and dust storms over time across the Great Plains, "the county makes an excellent unit of analysis for topics that are regional in scale. It is general enough to be manageable yet precise enough to reveal detailed variations across large areas". Additionally, historical and current agricultural census data is reported at a county level in five-year cycles and could be overlaid for additional interpretation, if necessary (103). The GIS
Table 3 Nebraska historic shelterbelt plantings summary table quantifying total plantings per year in each participating county

\begin{tabular}{lll}
\hline Year Planted & Number of Shelterbelts & Counties \\
\hline 1935 & 66 & 5 \\
1936 & 408 & 11 \\
1937 & 701 & 14 \\
1938 & 2166 & 25 \\
1939 & 2257 & 39 \\
1940 & 1742 & 46 \\
1941 & 1605 & 45 \\
1942 & 1077 & 49 \\
\hline
\end{tabular}

database enabled the development of our maps displaying this evolution of the PSFP at a state and county scale. With such maps, it is possible to visualise change between layers and across scales, with the goal of summarising landscape change over time in the PSFP.

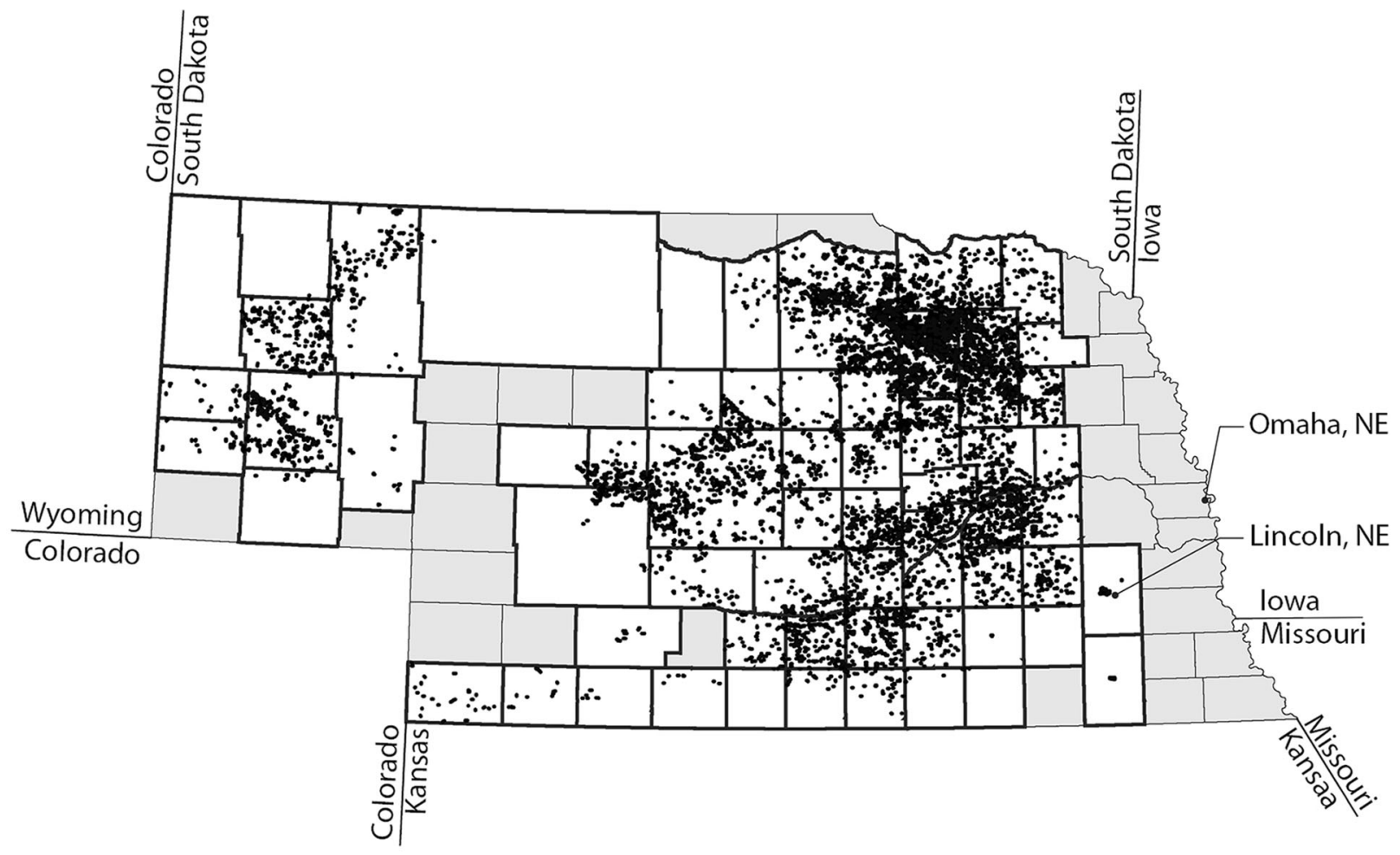

Nebraska Historical Inventory: Prairie State Forestry Project (1935-1942)

- Shelterbelts Planted

\section{$\square$ Participating Nebraska Counties}

\section{Non-Participating Nebraska Counties}

Fig. 7 Nebraska Historical Inventory: Prairie State Forestry Project (1935-1942). Map illustrating every shelterbelt planted across the state of Nebraska during the eight-year project (Source: the authors) 


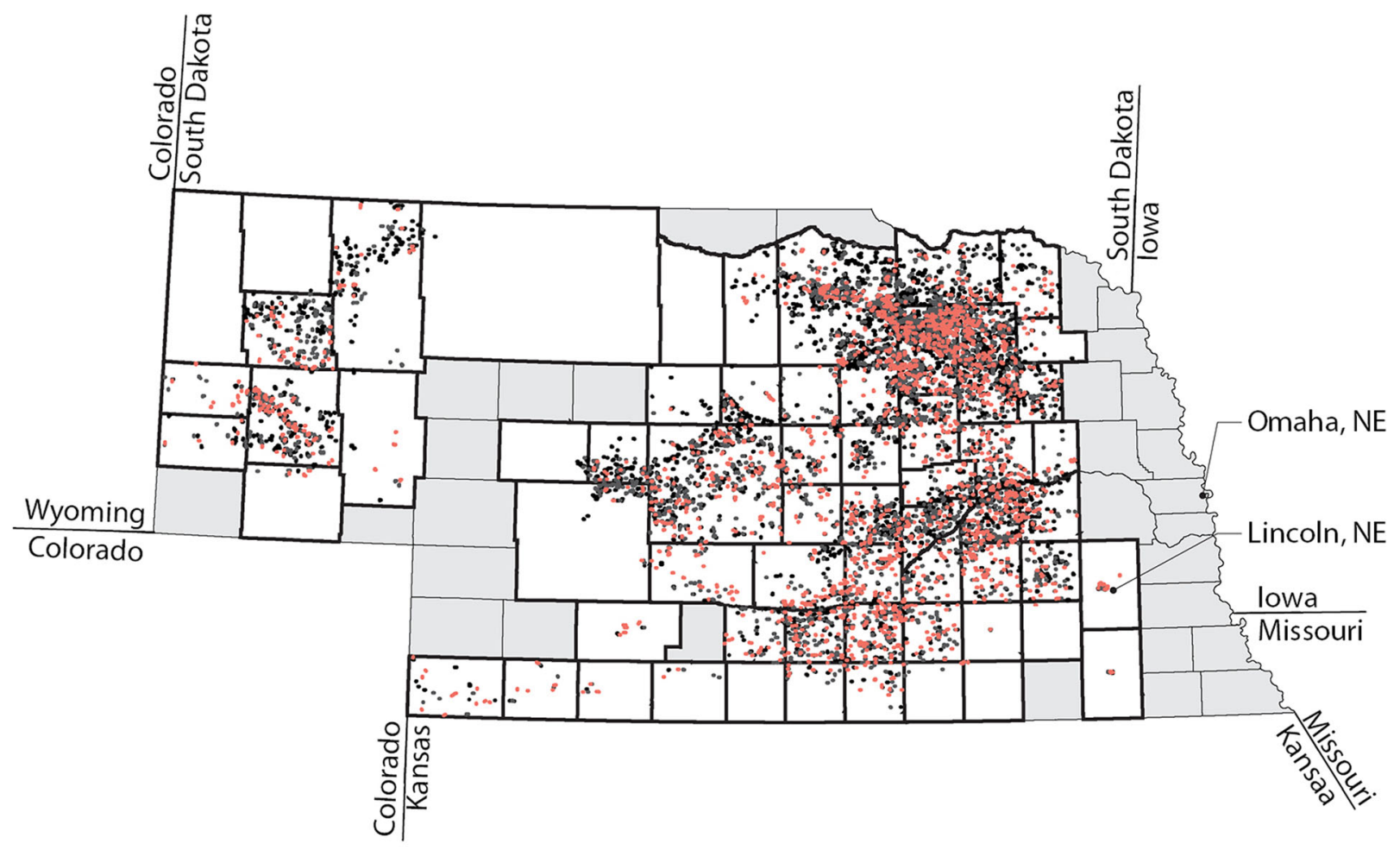

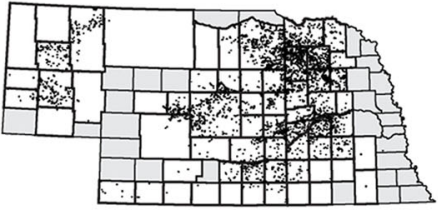

Intact Shelterbelts

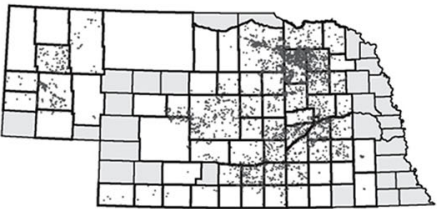

Partially Intact Shelterbelts

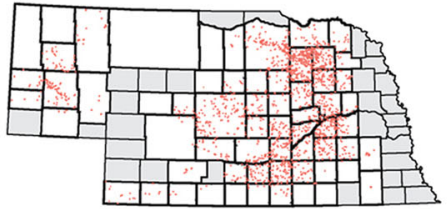

Removed Shelterbelts

\section{Nebraska Counties PSFP Existing Condition Map}

\section{- Intact Shelterbelts}

$\square$ Participating Nebraska Counties

\section{Removed Shelterbelts}

\section{Partially Intact Shelterbelts}

Fig. 82016 Nebraska PSFP Existing Conditions Map. Map illustrating the status of every shelterbelt planted across the state of Nebraska (Source: the authors)

\section{Results}

According to our analysis of the historical shelterbelt layer, the US Forest Service planted 10,022 shelterbelts in 62 participating Nebraska counties between 1935 and 1942. Each shelterbelt was identified by the year it was planted, illustrating the number of sites planted per year in participating counties. For example, during 1935, the first year of the project, the Forest Service only planted 66 shelterbelts in five participating counties, as compared to the highest planting year in 1939 when they planted 2257 shelterbelts across 39 participating counties. The majority of shelterbelts planted in the state occurred over a fiveyear period between 1938 and 1942, with 8842 shelterbelts planted, compared to a total of 1175 shelterbelts planted

Table 42016 existing condition of PSFP shelterbelts in the state of Nebraska

\begin{tabular}{|c|c|c|c|c|c|c|c|}
\hline Year & Number Intact & Percentage Intact & Number Partial & Percentage Partial & Number Removed & Percentage Removed & Total Planted \\
\hline 2016 & 4040 & $40 \%$ & 3573 & $36 \%$ & 2409 & $24 \%$ & 10,022 \\
\hline
\end{tabular}




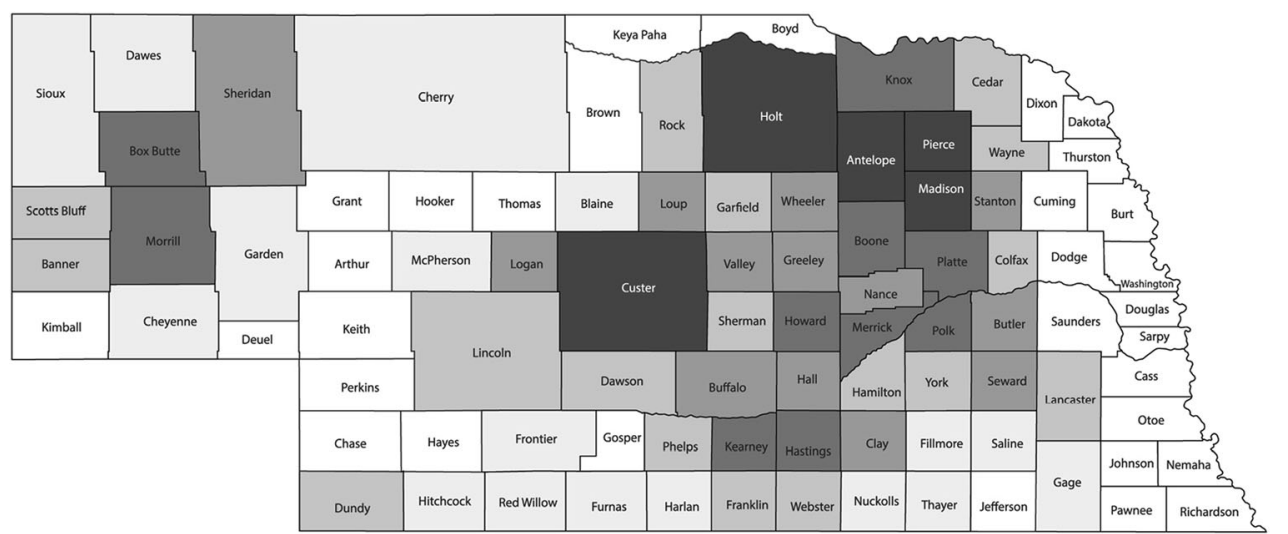

\author{
Nebraska PSFP Historic \\ Plantings per County \\ Number of Historical \\ Shelterbelts Planted per \\ County \\ 1-20 (17 counties) \\ 21-100 (15 counties) \\ 101-200 (15 counties) \\ 201-400 (10 counties) \\ 401-1200 (5 counties)
}

Fig. 9 Nebraska PSFP Historical Plantings per County. Map illustrating the number of historical shelterbelts planted per county (Source: the authors)

between 1935 and 1937 (see Fig. 7 and supporting summary Table 3).

Our analysis of the historical shelterbelt layers overlaid on a 2016 aerial photograph determined the existing condition of each belt across the state and revealed that $40 \%$ of the shelterbelts remained fully intact in 2016, resulting in 4040 remaining sites; $36 \%$ of the shelterbelts were partially intact, resulting in 3573 remaining sites; and only $24 \%$ had been removed, totalling a loss of 2409 shelterbelts (see Fig. 8 and supporting summary Table 4).

Maps and table comparison summaries at a county scale illustrated the numbers of originally planted shelterbelts compared to the numbers of fully intact shelterbelts remaining in each county. The historical shelterbelt layer also demonstrated the geographic density of sites planted across the state, with the largest amount of shelterbelt planting occurring in the northeastern counties of Antelope (1201 shelterbelts planted) and Holt (1136 shelterbelts planted) compared to the 32 participating counties that planted less than 100 shelterbelts (see Fig. 9 and supporting summary Table 5). Counties that planted over 50 shelterbelts-therefore achieving the Forest Service original land-use goals for systematic large-scale soil conservation-were analysed to identify eight counties with $50 \%$ or greater fully intact shelterbelts (see Fig. 10 and supporting summary Table 5). One interesting result revealed by our map is the ten western participating counties with planting sites located outside of the approved PSFP's planting zone. These counties have different soil conditions and precipitation rates compared to the eastern participating counties, potentially impacting tree survival and growth. Finally, our results documented that in 2016, 40\% of the shelterbelts remained fully intact, resulting in 4040 remaining sites and challenging previous anecdotal evidence that many historical Great Plains' shelterbelts had been removed from the landscape.

\section{Discussion}

The PSFP represents a significant moment in the history of ecological engagement in the Great Plains. This heritage, however, has been at risk due to a lack of coordinated monitoring efforts, with the current status of historical shelterbelts unknown. The historical GIS mapping method identified the location and provided supporting documentation for the physical evidence of the remaining PSFP shelterbelts across Nebraska. Our Nebraska Historical Inventory Map (Fig. 7) shows the over 70-year-old history of government-funded conservation efforts in cooperation with landowners to plant thousands of shelterbelts on private land across the state. Despite the importance of this New Deal project, a map visualising the full extent of the shelterbelt conservation planting effort did not exist prior to our research.

Another important piece of information created by our GIS database is the ability to identify the existing condition of each shelterbelt planted, thereby illustrating the progression of the conservation effort over time. Our 2016 Nebraska PSFP Existing Conditions Map (Fig. 8) is the first to identify the current status of every shelterbelt planted in the state. Prior to its generation, only anecdotal evidence existed regarding the status of the PSFP shelterbelts, making it impossible to advance comprehensive large-scale preservation and conservation initiatives. In fact, our research illustrated that $40 \%$ of the shelterbelts remained fully intact in 2016, highlighting the opportunity for new lines of inquiry regarding the historic conservation effort.

Our comprehensive countywide maps, Nebraska PSFP Historical Plantings per County (Fig. 9) and Nebraska PSFP Existing Conditions of Intact Planting per County (Fig. 10), provided a foundation to analyse the landscape's continuity and change at a smaller scale. The ability for a cultural resource manager to determine a shelterbelt's 
Table 52016 inventory and existing condition of Nebraska PSFP (1935-1942) in each participating county listed in alphabetical order

\begin{tabular}{|c|c|c|c|c|c|c|c|}
\hline County & Number Intact & Percentage Intact & Number Partial & Percentage Partial & Number Removed & Percentage Removed & Total Planted \\
\hline$\overline{\text { Adams }}$ & 67 & 27 & 78 & 31 & 104 & 42 & 249 \\
\hline Antelope & 364 & 30 & 544 & 45 & 293 & 24 & 1201 \\
\hline Banner & 10 & 29 & 17 & 50 & 7 & 21 & 34 \\
\hline Blaine & 14 & 82 & 2 & 12 & 1 & 6 & 17 \\
\hline Boone & 157 & 52 & 81 & 27 & 62 & 21 & 300 \\
\hline Box Butte & 65 & 29 & 120 & 53 & 42 & 19 & 227 \\
\hline Buffalo & 60 & 37 & 41 & 25 & 61 & 38 & 162 \\
\hline Butler & 81 & 48 & 40 & 24 & 47 & 28 & 168 \\
\hline Cedar & 50 & 62 & 13 & 16 & 18 & 22 & 81 \\
\hline Cherry & 3 & 75 & 1 & 25 & 0 & 0 & 4 \\
\hline Cheyenne & 3 & 27 & 4 & 36 & 4 & 36 & 11 \\
\hline Clay & 20 & 20 & 45 & 45 & 36 & 36 & 101 \\
\hline Colfax & 10 & 29 & 14 & 40 & 11 & 31 & 35 \\
\hline Custer & 392 & 49 & 254 & 32 & 160 & 20 & 806 \\
\hline Dawes & 4 & 100 & 0 & 0 & 0 & 0 & 4 \\
\hline Dawson & 17 & 22 & 23 & 30 & 36 & 47 & 76 \\
\hline Dundy & 10 & 40 & 4 & 16 & 11 & 44 & 25 \\
\hline Fillmore & 0 & 0 & 2 & 100 & 0 & 0 & 2 \\
\hline Franklin & 10 & 40 & 8 & 32 & 7 & 28 & 25 \\
\hline Frontier & 5 & 33 & 1 & 7 & 9 & 60 & 15 \\
\hline Furnas & 1 & 11 & 4 & 44 & 4 & 44 & 9 \\
\hline Gage & 4 & 36 & 4 & 36 & 3 & 27 & 11 \\
\hline Garden & 5 & 38 & 4 & 31 & 4 & 31 & 13 \\
\hline Garfield & 25 & 46 & 21 & 39 & 8 & 15 & 54 \\
\hline Greeley & 64 & 56 & 33 & 29 & 18 & 16 & 115 \\
\hline Hall & 58 & 30 & 55 & 28 & 82 & 42 & 195 \\
\hline Hamilton & 30 & 30 & 41 & 41 & 29 & 29 & 100 \\
\hline Harlan & 0 & 0 & 1 & 100 & 0 & 0 & 1 \\
\hline Hitchcock & 5 & 31 & 5 & 31 & 6 & 38 & 16 \\
\hline Holt & 521 & 46 & 422 & 37 & 193 & 17 & 1136 \\
\hline Howard & 130 & 43 & 101 & 34 & 68 & 23 & 299 \\
\hline Kearney & 57 & 27 & 94 & 44 & 62 & 29 & 213 \\
\hline Knox & 218 & 55 & 126 & 32 & 54 & 14 & 398 \\
\hline Lancaster & 4 & 12 & 13 & 38 & 17 & 50 & 34 \\
\hline Lincoln & 40 & 53 & 27 & 36 & 9 & 12 & 76 \\
\hline Logan & 84 & 58 & 43 & 30 & 18 & 12 & 145 \\
\hline Loup & 80 & 70 & 21 & 18 & 13 & 11 & 114 \\
\hline Madison & 191 & 44 & 133 & 31 & 107 & 25 & 431 \\
\hline McPherson & 14 & 78 & 4 & 22 & 0 & 0 & 18 \\
\hline Merrick & 91 & 37 & 99 & 40 & 59 & 24 & 249 \\
\hline Morrill & 110 & 31 & 164 & 47 & 76 & 22 & 350 \\
\hline Nance & 60 & 47 & 31 & 24 & 37 & 29 & 128 \\
\hline Nuckolls & 1 & 17 & 3 & 50 & 2 & 33 & 6 \\
\hline
\end{tabular}


Table 52016 inventory and existing condition of Nebraska PSFP (1935-1942) in each participating county listed in alphabetical order (Continued)

\begin{tabular}{|c|c|c|c|c|c|c|c|}
\hline County & Number Intact & Percentage Intact & Number Partial & Percentage Partial & Number Removed & Percentage Removed & Total Planted \\
\hline Phelps & 17 & 25 & 29 & 43 & 22 & 32 & 68 \\
\hline Pierce & 235 & 38 & 234 & 38 & 143 & 23 & 612 \\
\hline Platte & 78 & 32 & 74 & 30 & 92 & 38 & 244 \\
\hline Polk & 116 & 35 & 123 & 37 & 91 & 28 & 330 \\
\hline Red Willow & 1 & 14 & 2 & 29 & 4 & 57 & 7 \\
\hline Rock & 22 & 65 & 4 & 12 & 8 & 24 & 34 \\
\hline Saline & 0 & 0 & 0 & 0 & 1 & 100 & 1 \\
\hline Scotts Bluff & 6 & 14 & 15 & 35 & 22 & 51 & 43 \\
\hline Seward & 58 & 44 & 49 & 37 & 24 & 18 & 131 \\
\hline Sheridan & 65 & 41 & 72 & 45 & 23 & 14 & 160 \\
\hline Sherman & 12 & 24 & 20 & 39 & 19 & 37 & 51 \\
\hline Sioux & 1 & 100 & 0 & 0 & 0 & 0 & 1 \\
\hline Stanton & 93 & 57 & 44 & 27 & 25 & 15 & 162 \\
\hline Thayer & 0 & 0 & 0 & 0 & 2 & 100 & 2 \\
\hline Valley & 38 & 35 & 39 & 36 & 32 & 29 & 109 \\
\hline Wayne & 15 & 47 & 7 & 22 & 10 & 31 & 32 \\
\hline Webster & 11 & 26 & 19 & 45 & 12 & 29 & 42 \\
\hline Wheeler & 103 & 54 & 57 & 30 & 32 & 17 & 192 \\
\hline \multirow[t]{2}{*}{ York } & 34 & 23 & 44 & 30 & 69 & 47 & 147 \\
\hline & 4040 & 40 & 3573 & 36 & 2409 & 24 & 10,022 \\
\hline
\end{tabular}

significance and assess its integrity within the context of the enormous PSFP is critical for a National Register nomination. The GIS data set, for example, can be queried to identify the counties with the oldest remaining fully intact shelterbelts across the state, with the goal of identifying the first shelterbelt planted in the state. On the other hand, an additional county-scale inquiry could also determine the counties with the largest number and percentage of intact shelterbelts across the state to identify concentrated geographic areas with shelterbelts in need of future conservation measurements.

\section{Contribution of mapping method}

Spatialising the PSFP's archival documents into GIS created a foundation to generate a data set connecting cultural and natural resources. Therefore, the historical GIS method enabled mapping of a cultural landscape across a larger spatial scale than typically addressed by cultural

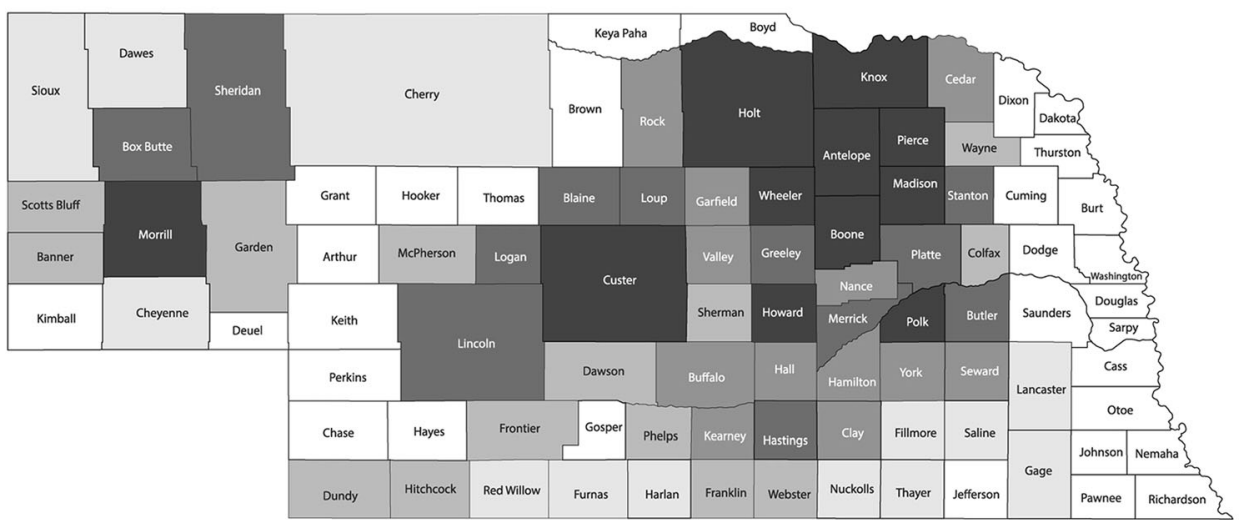

Nebraska PSFP Existing Conditions of Intact Planting per County Numbers of Remaining Intact Shelterbelts per County

0-4 (13 counties)

5-20 (16 counties)

21-60 (12 counties)

61-100 (10 counties)

101-521 (11 counties)

Fig. 10 Nebraska PSFP Existing Conditions of Intact Plantings per County. Map illustrating the number of intact shelterbelts per county in 2016 (Source: the authors) 
resource managers. The integration of both historical and contemporary sources provided useful information for cultural landscape research and expanded the tools available for large-scale cultural landscape analysis by identifying the extent of the historical and current condition of shelterbelts. If archival sources are identified, the historical GIS method could be applied by cultural resource managers working on other heritage projects, including Historic American Landscapes Survey (HALS) reports, National Register nominations, cultural landscape reports, historic landscape studies related to Section 106 and 110 reviews, and preliminary archaeological surveys.

\section{Significance and impact}

In the case of the Prairie States Forestry Project, the process for digitising and disseminating previously inaccessible primary source documents is an act of preservation that opens up opportunities for future large-scale landscape conservation projects. The ability to document the PSFP addresses a critical barrier for large-scale landscape preservation by laying the groundwork for physical evidence required to nominate a site potentially eligible for the National Register. The historical GIS mapping method established for the study area of Nebraska can be applied to the PSFP shelterbelts in South Dakota and North Dakota, with the goal of inventorying and evaluating the project across political and jurisdictional boundaries. Finally, due to the scope and national scale of the New Deal, several significant heritage conservation projects remain undocumented and would benefit from a similar research method laying the groundwork for the potential nomination process.

The GIS datasets are not only critical to cultural resource preservation but can also be applied to future soil and shelterbelt management and conservation research by serving as a starting point for analysing the impact of shelterbelts on the land. Our maps visualise shelterbelts change over time, and the data can be used to locate existing PSFP shelterbelts in need of renovation. Our dataset, for example, was used in the TOFii Trees Outside Forests Image-Based Inventory by researchers from the USDA Forest Service Forest Inventory \& Analysis, Northern Research Station and USDA National Agroforestry Center as baseline data to identify linear shelterbelts to test their methods using remote sensing, object-based image analysis, and computer-learning algorithms to map trees in agriculturally dominated landscapes. Additionally, our mapping method and data are disseminated on the USFS website Windbreaks of the Great Plains, aimed at expanding conservation knowledge in the region (Kellerman et al. 2019). The ability to share information gained from historical research 'contributes a powerful cultural or human dimension to conservation efforts' (NPS 2014, 13). Connecting the PSFP story to individual sites, counties, and the entire state establishes a compelling opportunity to engage communities in stewardship to preserve historic sites and protect the land (NPS 2014, 13).

\section{Limitations}

The creation of our Nebraska PSFP Historical Inventory Map is a milestone in a multi-year research project to create a comprehensive GIS database for all three Forestry Project northern prairie states. This effort has required extensive archival research to code the spatial data properly; despite the location of archival sources for three participating states (Nebraska, South Dakota, and North Dakota) the NAC archive does not have comprehensive documentation for the three participating southern states (Texas, Oklahoma, and Kansas), making it challenging at this time to map the entire six-state project with similar archival data. Additionally, like all cultural resource mapping methods, our method offers an incomplete view of landscape history. The data created for our 2016 Nebraska PSFP Existing Conditions Map and our 2016 Nebraska PSFP Existing Conditions of Intact Planting per County is limited to the period of the aerial photography, making it challenging to identify and update landscape change on an annual basis. Despite the increased availability of primary-source evidence, additional fieldwork will be necessary to verify the existence of the shelterbelts and health of the plantings. Although data on the original species planted, for example, is available in portions of the archival records, the software used in our mapping process did not allow for the identification of existing plant material and therefore was not used as a criterion for evaluation when classifying each shelterbelt's 2016 condition (Fig. 11). Additionally, the method for classifying shelterbelts as 'partially intact' resulted in a broad range $(6 \%-74 \%)$ that included 3573 sites, and should be re-evaluated to provide greater specificity for measuring continual conservation performance.

\section{Conclusion}

The historical GIS mapping method for the PSFP in Nebraska enabled the documentation of a number of smallscale sites (over 10,000) that are simultaneously contextualised within the larger cultural landscape, providing a critical starting point for inventorying and evaluating the existing condition of historically significant shelterbelts. The ability to digitally document the PSFP addresses a critical barrier for large-scale landscape preservation by laying the groundwork (otherwise impossible) for the physical evidence needed for a potentially eligible site to be nominated to the National Register.

A historical GIS method can be applied by cultural resource managers working to document and manage large-scale heritage landscapes. As historian Donahue (2008, 174) has stated, 'based on experience, historical 

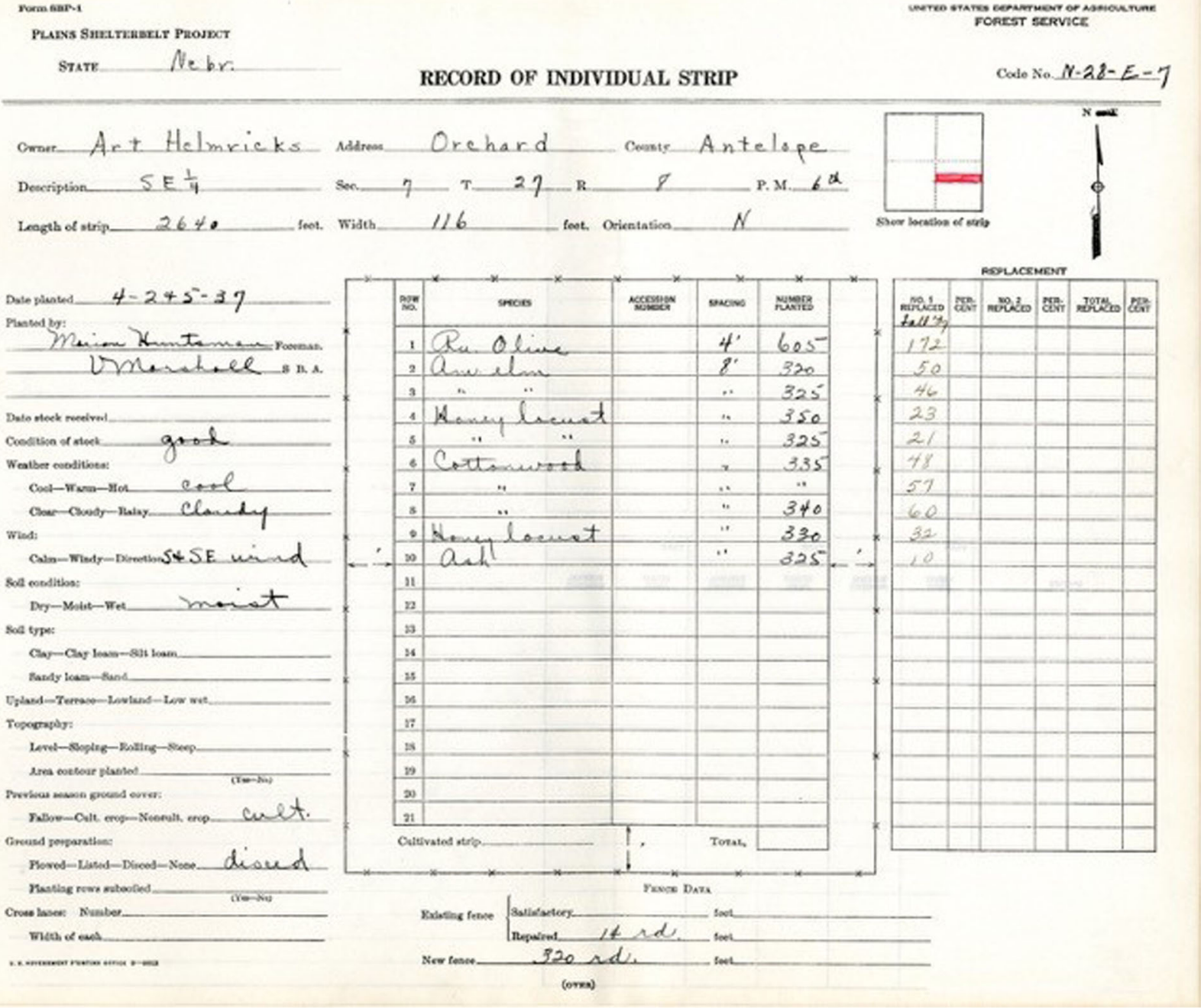

Fig. 11 Archival Source Record of Individual Planting. US Department of Agriculture, Forest Service. (Source: National Agroforestry Centre Forest Service)

GIS mapping can be of great service to these efforts [conservation]'. Researchers at Harvard Forest, for example, applied a historical GIS method to direct conservation land management across the state of Massachusetts, connecting knowledge of past ecological change with current management plans (174). The ability to connect information gained from historical research to conservation efforts creates a powerful tool linking cultural and natural resources.

\section{Future research}

Heritage landscape preservation relies on advocacy and engaging the public with credible primary source materials (Ammon 2018, 28). Because the majority of sites in the PSFP are on private land, public engagement is essential to advancing preservation and conservation projects across the state. Through attractive and accessible websites, digital heritage projects can introduce new audiences to forgotten heritage landscapes like the Prairie States Forestry Project.

For example, the online digital heritage project, The Living New Deal (https://livingnewdeal.org/), introduces archival documents to new audiences, lending new opportunities for preservation work. The website, housed in the Department of Geography at the University of California Berkeley, has become a tremendous New Deal resource. The digital mapping component is central to the website's mission to disseminate 'the immense riches of the New Deal public works' to researchers, educators, and the general public across the United States. The project team is working with volunteers across the country to map New Deal public work projects, a vital initiative considering that 'because New Deal public works were rarely marked, the era's contribution to American life goes largely unseen and unappreciated' (Walker et al. 2019). Like many significant New Deal projects presented as part of the Living New 
Deal, a future research goal for the Prairie State Forestry Project's archival source material and corresponding GIS dataset is to make the sources publicly accessible. Therefore, the accessibility of data would allow individuals or agencies working with wider communities in the fields of preservation and stewardship to include the Prairie States Forestry Project as an important part of rural heritage documentation.

\section{Acknowledgements}

This project is supported by funding from the US Forest Service Agreement \#19 CR11330152045 and the University of Nebraska College of Architecture. The authors would like to thank Gary Bentrup, Todd Kellerman, and Richard Straight from the USDA National Agroforestry Center for their support and feedback. Additionally, we would like to thank the anonymous reviewers of this journal for their peer-review comments on this paper.

\section{Authors' contributions}

Sarah Karle conceived of the study, performed analyses, and drafted the manuscript. Richard Carman established the historical GIS method, created the baseline historical dataset, and performed analyses. All authors read and approved the final manuscript and supporting images.

\section{Funding}

This project is supported by funding from the U.S. Forest Service Agreement \#19 CR11330152045 and the University of Nebraska College of Architecture.

\section{Availability of data and materials}

The baseline historical dataset for the Nebraska section of the Prairie States Forestry Projects is forthcoming publication by the USDA National Agroforestry Center.

\section{Competing interests}

The authors declare that they have no competing interests.

\section{Author details}

${ }^{1}$ University of Nebraska-Lincoln, Lincoln, Nebraska, USA. ${ }^{2}$ Independent

Researcher, Lincoln, Nebraska, USA

Received: 20 November 2019 Accepted: 16 December 2019

Published online: 25 March 2020

\section{References}

Ammon, Francesca. 2018. Digital Humanities and the Urban Built Environment: Preserving the Histories of Urban Renewal and Historic Preservation. Preservation Education \& Research 10: 11-31.

Barrett, Brenda. 2018. The Challenges of Conserving Cultural Resources on a Landscape Scale. The Living Landscape Observer, September 29 https:// livinglandscapeobserver.net/the-challenge-of-cultural-resources-on-alandscape-scale. Accessed 4 July 2019.

Cunfer, Geoff. 2008. Scaling the Dust Bowl . In Placing History: How Maps, Spatial Data, and GIS Are Changing Historical Scholarship, ed. Anne Kelly Knowles and Amy Hiller, 95-121. Redlands: ESRI Press.

Donahue, Brian. 2008. Mapping Husbandry in Concord: GIS as a Tool for Environmental History. In Placing History: How Maps, Spatial Data, and GIS Are Changing Historical Scholarship, ed. Anne Kelly Knowles and Amy Hiller, 151177. Redlands: ESRI Press.

Droze, Wilman. 1977. Trees Prairies \& People. Houston: Texas Woman's University Press. Gregory, lan. 2003. A Place in History: A Guide to Using GIS in Historical Research. Oxford: Oxbow Books

Kellerman, Todd, et al. 2019. "Windbreaks of the Great Plains." https://usfs.maps. arcgis.com/apps/MapSeries. Accessed 12 Nov 2019.

Knowles, Anne. 2005. Emerging Trends in Historical GIS. Historical Geography 33: 7-13. Knowles, Anne Kelly, and Amy Hillier, eds. 2008. Placing History: How Maps, Spatia Data, and GIS Are Changing Historical Scholarship. Redlands: ESRI Press.

Liknes, Greg, Dacia M. Meneguzzo, and Todd A. Kellerman. 2017. Shape Indexes for Semi-Automated Detection of Windbreaks in Thematic Tree Cover Maps from The Central United States. International Journal of Applied Earth Observation and Geoinformation 59: 167-174.
Loughlin, Amanda, and Elizabeth Rosin. 2019. New Deal-era Resources in Nebraska. In National Register of Historic Places Multiple Property Documentation Form, NPS \#100004611, November 19, 2019.

McClelland, Linda Flint, J. Timothy Keller, Genevieve P. Keller, and Robert Z. Melnick. 1999. Guidelines for Evaluating and Documenting Rural Historic Landscapes. In National Register Bulletin 30, rev. ed., 3. Washington, D.C.: U.S. Department of the Interior, National Park Service.

McLeman, Robert, Juliette Dupre, Lea Berrange Ford, James Ford, Konrad Gajewski, and Gregory Marchildon. 2014. What we learned from the Dust Bowl: Lessons in Science, Policy, and Adaptation. Population and Environment 33 (4): 417-440.

NAIP (United States Department of Agriculture's National Agriculture Imagery Program). 2016. "NAIP Imaginary." https://www.fsa.usda.gov/programs-andservices/aerial-photography/imagery-programs/naip-imagery. Accessed 12 Nov 2019.

NPS (National Park Service). 2014. Expanding Horizons: Highlights from the National Workshop on Large Landscape Conservation. In Proceedings from the National Workshop on Large Landscape Conservation, Washington, D.C., October 23-24.

NRCS (United States Department of Agriculture's Natural Resource Conservation Service). 2016. "Geospatial Data Gateway." https://datagateway.nrcs.usda.gov. Accessed 12 Nov 2019

Perry, E.L. 1942. History of the Prairie States Forestry Project. In US Forest Service. Unpublished manuscript, June 18, 1942. Lincoln: National Agroforestry Center.

Roberts, Paul. 1940. Historical Inquiry Letter to U.S. Forest Service. November 28, 1940. Lincoln: Prairie State Forestry Archive.

Rumsey, David, and Meredith Williams. 2002. Historical Maps in GIS. In Past Time, Past Place: GIS for History, ed. Anne Kelly Knowles, 1-18. Ann Arbor: University of Michigan Press.

Sabol, Christina, Ned Crankshaw, Brian Lee and Douglas Appler. 2018. GIS Mapping Innovations for Documenting Change in Rural Cultural Landscapes. Project report. National Center for Preservation Training and Technology. https://www.ncptt.nps.gov/blog/gis-mapping-innovations-2017-15/.

Walker, Richard, et al. 2019. "Living New Deal." https://livingnewdeal.org. Accessed 4 July 2019.

Woolner, David. 2010. FDR and the New Deal Response to an Environmental Catastrophe. In Roosevelt Institute Reimaging the Rules https:// rooseveltinstitute.org/fdr-and-new-deal-response-environmental-catastrophe. Accessed 4 July 2019

\section{Publisher's Note}

Springer Nature remains neutral with regard to jurisdictional claims in published maps and institutional affiliations.

\section{Submit your manuscript to a SpringerOpen ${ }^{\circ}$ journal and benefit from:}

- Convenient online submission

- Rigorous peer review

- Open access: articles freely available online

- High visibility within the field

Retaining the copyright to your article

Submit your next manuscript at $>$ springeropen.com 